\title{
Effect of stocking density and diet on growth and survival of post-larvae of the taquilla clam Mulinia edulis cultivated in sand in a hatchery
}

Efecto de la densidad de cultivo y dieta sobre el crecimiento y supervivencia de postlarvas de la almeja taquilla Mulinia edulis cultivadas en arena en un hatchery

\section{Doris Oliva ${ }^{1}$, Alejandro Abarca ${ }^{1,2}$, Rodrigo Gutiérrez ${ }^{1}$, Ángela Celis ${ }^{1}$, Lucía Herrera ${ }^{1}$ and Vanessa Pizarro}

\begin{abstract}
${ }^{1}$ Departamento de Biología \& Ciencias Ambientales, Facultad de Ciencias, Universidad de Valparaíso, Centro de Investigación y Gestión de los Recursos Naturales (CIGREN), Gran Bretaña \#1111, Valparaíso, Chile. doris.oliva@uv.cl

${ }^{2}$ Programa de Magister en Acuicultura, Facultad de Ciencias del Mar, Universidad Católica del Norte, Larrondo 1281, Coquimbo, Chile
\end{abstract}

\begin{abstract}
Resumen.- Con el objeto de contribuir al desarrollo de la tecnología para el cultivo comercial de la almeja taquilla Mulinia edulis, se determinó el efecto de la densidad de cultivo y el tipo de dieta en el crecimiento y sobrevivencia de las postlarvas. Cultivos larvales de 14 días, dieron origen a postlarvas que fueron cultivadas en sistemas cerrados con fondo de arena por 30 días, a densidades de 5, 10 y 20 postlarvas $\mathrm{cm}^{-2}$. Para determinar el efecto del tipo de dieta se ofrecieron 3 dietas monoespecíficas: Isochrysis aff galbana (clon T-ISO), Phaeodactylum tricornotum y Tetraselmis suecica y 2 dietas mixtas: I. galbana (clon T-ISO) (50\%) - P. tricornotum (50\%) y I. galbana (clon T-ISO) (33\%) - P. tricornotum (33\%) - T. suecica (33\%) a una ración fija de $100.000 \mathrm{cel} \mathrm{ml}^{-1}$ día $^{-1}$. El cultivo a una densidad 5 postlarvas $\mathrm{cm}^{-2}$ generó la mayor longitud valvar que fue de $1707 \pm 200 \mu \mathrm{m}$ a una edad de 44 días. Las postlarvas alimentadas con Isochrysis galbana (clon T-ISO) alcanzaron las mayores longitudes valvares, $2225 \pm 430 \mu \mathrm{m}$ a una edad de 50 días. La supervivencia de las postlarvas fue alrededor del $50 \%$ y no fue afectada por los diferentes niveles de parámetros analizados (densidad de cultivo y dieta).

Palabras clave: Cultivo de almejas, Mactridae, hatchery

Abstract.- We determined the effect of stocking density and type of diet on the growth and survival of post-larvae of the taquilla clam Mulinia edulis, as a contribution to the development of technology for the commercial cultivation of this species. Larval cultures of 14 days gave rise to postlarvae which were cultivated in closed systems in sand for 30 days, at densities of 5, 10 and 20 post-larvae $\mathrm{cm}^{-2}$. To determine the effect of diet, 3 monospecific diets (Isochrysis aff galbana (clone T-ISO), Phaeodactylum tricornotum and Tetraselmis suecica) and 2 mixed diets [I. galbana (clon T-ISO) (50\%) - P. tricornotum (50\%) and I. galbana (clon T-ISO) (33\%) - P. tricornotum (33\%) - T. suecica (33\%)] were provided at a fixed total ration of 100,000 cell ml$^{-1}$ day ${ }^{-1}$. Cultivation at a density of 5 post-larvae $\mathrm{cm}^{-2}$ produced the greatest valve length at age 44 days, 1707 $\pm 200 \mu \mathrm{m}$. Postlarvae fed with Isochrysis galbana (clone T-ISO) had the greatest valve length, $2225 \pm 430 \mu \mathrm{m}$ at age 50 days. The survival of postlarvae was about $50 \%$, and was not affected by the different levels of the parameters analyzed (cultivation density and diet).
\end{abstract}

Key words: Clam culture, Mactridae, hatchery

\section{INTRODUCTION}

Mulinia edulis (King \& Broderip, 1832), commonly called the 'taquilla' clam, is one of 6 species of clam commercially exploited in Chile (Abarca et al. 2012). Extraction is restricted to individuals with a valve length of at least 55 $\mathrm{mm}$ and is only performed by local fishermen from historical fishery grounds and management areas of benthic resources (Oliva et al. 2005). The decrease in landings recorded in Chile in the last decade of the different species of clams (SERNAPESCA 2010) has generated problems in the supply of raw material for the processing plants which export these products, mainly to the European Community and countries of the Asian Pacific (Oliva et al. 2005).

Among the Chilean clams, M. edulis is a dioecious species especially apt for the artificial management of reproduction for cultivation, due to the presence of sexually mature individuals during the entire year, which 
permits to obtain competent gametes for larval cultures (Oliva et al. 2005).

The settling process initiated with the appearance of a contractile organ covered with cilia, the foot. This occurred at a mean valve length of $200 \mu \mathrm{m}$ (14 days old). In contrast to other bivalves, the postlarvae of Mulinia edulis do not have an eye spot. The swimming pediveliger transforms into a benthic organism by eliminating the velum after about 22 days. The metamorphosed larva has all the morphological characteristics of an adult at 28 days, when it has a valve length of $1 \mathrm{~mm}$. The shell continues to have a translucent white color, which allows all its internal organs to be seen (Oliva et al. 2005).

According to Wang et al. (2008) a large scale clam culture industry depends on seed production. Therefore, nutrition in larval stages plays a key role in successful seed rearing. Temperature and food availability are the principal factors which affect the growth rate of clam larvae (Albentosa et al. 1996a, Liu et al. 2006). Diet requirements are specific for different clam species (Albentosa 1996b, Helm \& Laing 1987), therefore it is critical for successful culture to select an adequate diet (Tang et al. 2006).

A number of studies have evaluated diets for the larval stage of different species of clams: Mercenaria mercenaria, Tapes semidecussata (Helm \& Laing 1987), Meretrix meretrix (Tang et al. 2006), Ruditapes philippinarum (Yan et al. 2006), Paphia malabarica (Raghavan \& Gopinathan 2008), as well as for other bivalve species such as the oyster Pinctada margaritifera (Southgate et al. 1998, Martínez-Fernández et al. 2006) and the scallop Argopecten ventricosus-circularis (LoraVilchis \& Maeda-Martínez 1997).

Cultivation density is an important factor which affects not only the rate of larval development, but also the size at the end of the pelagic phase, settling and metamorphosis. Taylor et al. (1998), in larval cultures of the silver-lip pearl oyster Pinctada maxima, and Liu et al. (2006), with the clam Meretrix meretrix, showed that larval density affects both the size of the larvae and the time they take to reach the stage of metamorphosis.

The great majority of the density studies performed with filtering mollusks have used volumetric rather than area densities in the postlarval stage (Taylor et al. 1998, Doroudi \& Southgate 2000). Density studies (individuals per $\mathrm{cm}^{2}$ or $\mathrm{m}^{2}$ ) have focused on seeds and individuals longer than 3 mm (Hadley \& Manzi 1984, Doménech 1994, Liu et al. 2002, Royo et al. 2005 a, b).
To develop the culture technology of $M$. edulis it is important to know the optimum diet and cultivation density in postlarvae, in order to scale them appropriately. There is currently a lack of information on the influence of diet and stocking density on the development of $M$. edulis postlarvae. We hypothesized that low stocking density will result in a better growth rate and better survival compared with higher stocking densities. We also expect that mixed diets will perform better than monospecific diets in the growth and survival of postlarvae. Therefore, the aim of this study is to evaluate the effects of these factors on the growth and survival of M. edulis postlarvae cultivated in sand.

\section{Materials AND Methods}

The experimental culture of postlarvae of taquilla clam was performed in the hatchery of the Pesquera San José

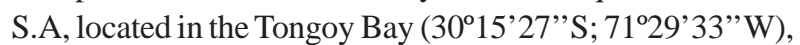
Coquimbo, Chile, from September, 2002 to June, 2003.

Broodstock were extracted from a natural bank located

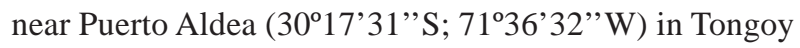
Bay. The postlarvae (hereafter PL) were obtained from 14-day larval cultures with an initial density of 10 larvae $\mathrm{ml}^{-1}$, fed with a ration of 25.000 cell ml $^{-1}$ day $^{-1}$ and cultivated in sea water filtered at $1 \mu \mathrm{m}$ and sterilized with UV light, at a temperature of $18 \pm 1^{\circ} \mathrm{C}$. For postlarval settlement sand was used as substrate and was first sifted in a $300 \mu \mathrm{m}$ sieve and sterilized at $100^{\circ} \mathrm{C}$ for $5 \mathrm{~min}$. The cultures were controlled every 6 or 8 days. On every occasion, the sand was sifted in a $300 \mu \mathrm{m}$ sieve (USA standard ASTM N`50). The PL retained in the sieve were counted to determine survival, and the shell length was measured in 30 individuals selected at random to analyze growth. The sea water was changed every 2 days and the cultures were maintained with continuous aeration and with a photoperiod of $12 \mathrm{~h}$ light and $12 \mathrm{~h}$ dark in containers of $160 \mathrm{~cm}^{2}$.

\section{EFFECT OF STOCKING DENSITY ON POSTLARVAL CULTURE}

PL of $M$. edulis with an initial length $265 \pm 12 \mu \mathrm{m}$ were maintained for 30 days with sea water filtered at $1 \mu \mathrm{m}$ and sterilized with UV light at a temperature of $17 \pm 1^{\circ} \mathrm{C}$. They were fed with a mixture of Isochrysis galbana (90\%) and Phaeodactylum tricornutum (10\%). The food ration was 25,000 cell ml $^{-1}$ day $^{-1}$ for the first 7 days, 50,000 cell ml ${ }^{-1}$ day $^{-1}$ in the second week, 100,000 cell ml ${ }^{-1}$ day $^{-1}$ in the third week and 200,000 cell ml-1 day ${ }^{-1}$ until the end of the experiment. 
The experiments of stocking density were performed in $50 \mathrm{~L}$ wooden trays covered with epoxy resin with a basal area of $0.5 \mathrm{~m}^{2}$ which were covered with $2 \mathrm{~cm}$ of sand. We tested 3 stocking densities, with 5, 10 and 20 postlarvae $\mathrm{cm}^{-2}\left(\mathrm{PL} \mathrm{cm} \mathrm{cm}^{-2}\right)$. The treatments were replicated 3 times; growth was evaluated every 8 days. Survival was evaluated at days 36 and 44, when the postlarvae had reached a size greater than the sieve mesh $(300 \mu \mathrm{m})$ and thus were retained on sifting.

\section{EFFECT OF DIET ON POSTLARVAL CULTURE}

The diet experiments were conducted with postlarvae which began with a valve length of $271 \pm 13 \mu \mathrm{m}$, from 19day larval cultures. The PL were cultivated in $1 \mathrm{~L}$ plastic trays with a basal area of $160 \mathrm{~cm}^{2}$ covered with $1 \mathrm{~cm}$ of sand, in micro-filtered sea water sterilized with UV light, at a temperature of $18^{\circ} \mathrm{C}$. The initial density was $6.54 \mathrm{PL}$ $\mathrm{cm}^{-2}$. The treatments consisted of 3 monospecific diets of microalgae: Isochrysis aff. galbana (clone T-ISO) (I), Phaeodactylum tricornutum $(P)$ and Tetraselmis suecica (T), and 2 mixed diets: I. galbana (clone T-ISO) (50\%) - P. tricornutum (50\%) (I/P) and I. galbana (clon T-ISO) (33\%) - P. tricornutum (33\%) - T. suecica (33\%) (I/P/T). All experiments had a total concentration of 100.000 cell ml$^{-1}$ day $^{-1}$ and were performed in triplicate; growth and survival were estimated every 6 days.

\section{Data analysis}

Normality of data was checked with Shapiro's and Wilks' tests. The effects of density and diet on the growth of postlarvae were analyzed using the non-parametric Kruskal-Wallis test. Significant differences between treatments means were determined by the a posteriori Mann-Whitney U test (Zar 1999). Survival data were arcsine transformed prior to statistical analysis. To determine the effect of culture density and diet on survival, we used ANOVA and Tukey's a posteriori test (Sokal \& Rohlf 1980). $P<0.05$ was used as the significance level for all tests. Data were analyzed with the statistical software STATISTICA version 6.0 (Statsoft Inc., Tulsa).

\section{Results}

\section{EFFECT OF STOCKING DENSITY ON POSTLARVAL CULTURE}

Figure 1 shows the growth of $M$. edulis PL cultured at different densities. At 22 days of age (6 days after the beginning of the experiment) valve length was not different among treatments; the overall mean was $502 \pm 5$ $\mu \mathrm{m}$, with a growth of $30 \mu \mathrm{m}$ day $^{-1}$. In the densities of 5 and $10 \mathrm{PL} \mathrm{cm} \mathrm{cm}^{-2}$ we eliminated one of the 3 replicates, which were contaminated with protozoa in the first week of culture.

Between the ages of 22 and 36 days the daily growth of the PL increased rapidly; the growth rate reached 86 $\mu \mathrm{m}$ day $^{-1}$ for the density $20 \mathrm{PL} \mathrm{cm}^{-2}$ and $102 \mu \mathrm{m}_{\text {day }^{-1}}$ for 5 $\mathrm{PL} \mathrm{cm}^{-2}$. At day 36, the PL cultivated at $20 \mathrm{PL} \mathrm{cm}^{-2}$ had the smallest size (1707 $\pm 200 \mu \mathrm{m})$, which was significantly different from the sizes reached by PL cultured at 5 and $10 \mathrm{PL} \mathrm{cm}^{-2}$, whose length reached $1931 \pm 260 \mu \mathrm{m}$ and 1856 $\pm 213 \mu \mathrm{m}$, respectively. The growth rate of the PL cultured at $5 \mathrm{PL} \mathrm{cm}{ }^{-2}$ remained at $103 \mu \mathrm{m}_{\text {day }}{ }^{-1}$ at age 44 days, while the PL cultured at 10 and $20 \mathrm{PL} \mathrm{cm}^{-2}$ decreased to $40 \mu \mathrm{m}$ day $^{-1}$ and $47 \mu$ day $^{-1}$, respectively. As a result, the mean valve length of the PL cultured at $5 \mathrm{PL} \mathrm{cm}^{-2}(2760 \pm 396$ $\mu \mathrm{m})$ was significantly greater than the length of those cultured at 10 and $20 \mathrm{PL} \mathrm{cm}^{-2}(2176 \pm 313 \mu \mathrm{m}$ and $2090 \pm$ $312 \mu \mathrm{m}$ ), respectively (Fig. 1).

Survival at 36 days of age was lower in the PL cultured at $20 \mathrm{PL} \mathrm{cm}^{-2}(27.5 \pm 4.4 \%)$, while those maintained at 5 or $10 \mathrm{PL} \mathrm{cm}^{-2}$ were not significantly different (Table 1 ). At the end of the experiment the treatment of $10 \mathrm{PL} \mathrm{cm}^{-2}$ still had the greatest survival (40\%), followed by $38 \%$ for the PL cultured at $5 \mathrm{PL} \mathrm{cm}^{-2}$ and $21.3 \%$ for the density of $20 \mathrm{PL}$ $\mathrm{cm}^{-2}$ (Table 1).

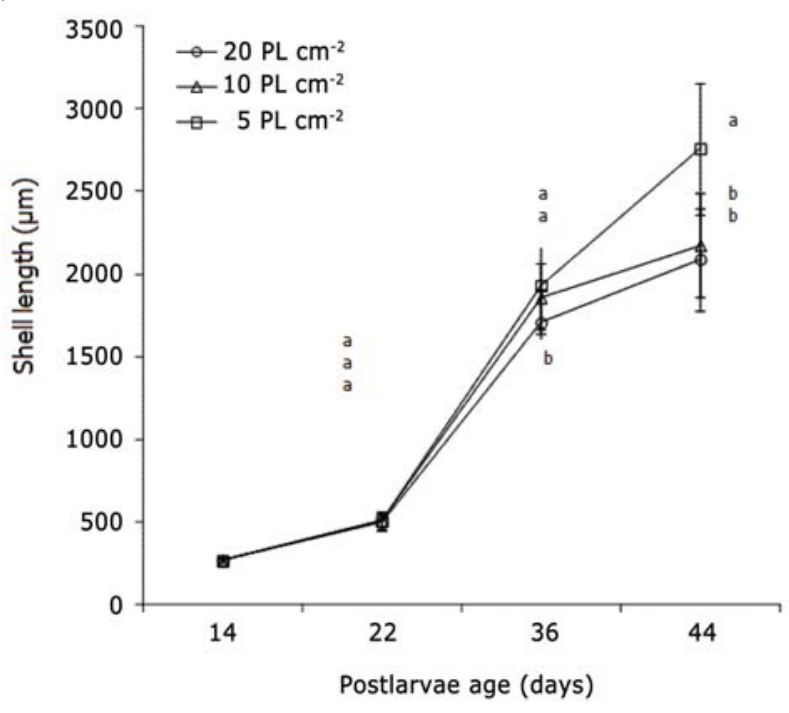

Figure 1. Growth of Mulinia edulis postlarvae reared in a closed system with sand at 3 culture densities $\left(5,10\right.$ and $\left.20 \mathrm{PL} \mathrm{cm}^{-2}\right)$. Means with different letters were significantly different $(P<0.05) /$ Crecimiento de postlarvas de Mulinia edulis cultivadas a 3 densidades (5, 10 and $20 \mathrm{PL} \mathrm{cm}^{-2}$ ) en un sistema cerrado con arena. Las medias con diferentes letras son significativamente diferentes $(P<0,05)$ 
Table 1. Survival (Mean \pm SD) of Mulinia edulis postlarvae (PL) cultured with a stocking density of 5,10 and $20 \mathrm{PL} \mathrm{cm}-2$. Means with different letters were significantly different $(P<0.05) /$ Supervivencia (Media $\pm \mathrm{DE}$ ) de postlarvas (PL) de Mulinia edulis cultivadas a densidades de 5,10 y $20 \mathrm{PL} \mathrm{cm}^{-2}$. Las medias con diferentes letras son significativamente diferentes $(P<0,05)$

\begin{tabular}{cccc}
\hline $\begin{array}{c}\text { Stocking Density/ } \\
\text { PL Age }\end{array}$ & \multicolumn{3}{c}{$\begin{array}{c}\text { Survival } \\
\text { (Mean } \pm \text { SD) }\end{array}$} \\
\hline Day 14 & 100 & 100 & 100 \\
Day 36 & $41 \pm 1$ (a) & $46 \pm 2$ (a) & $28 \pm 4(\mathrm{~b})$ \\
Day 44 & $38 \pm 10(\mathrm{a})$ & $40 \pm 9$ (a) & $21 \pm 1(\mathrm{a})$ \\
\hline
\end{tabular}

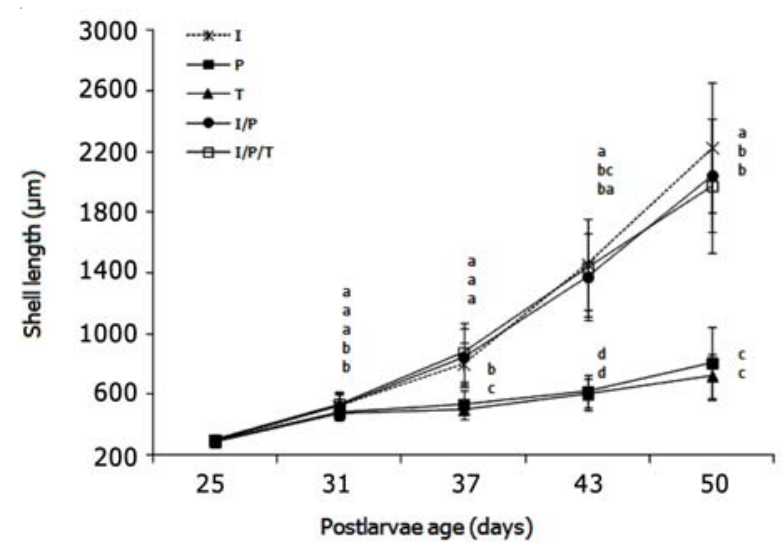

Figure 2. Growth of Mulinia edulis postlarvae reared in a closed system with sand with 5 diets [Isochrysis galbana (clone T-ISO) I, Phaeodactylum tricornotum $\mathrm{P}$, Tetraselmis suecica $\mathrm{T}$, I. galbana (clone T-ISO) - P. tricornotum I/P y I. galbana (clone T-ISO) - P. tricornotum- T. suecica I/P/T] / Crecimiento de postlarvas de Mulinia edulis cultivadas en un sistema cerrado con arena y alimentadas con 5 dietas [Isochrysis galbana (clone T-ISO) I, Phaeodactylum tricornotum $\mathrm{P}$, Tetraselmis suecica $\mathrm{T}$, I. galbana (clone T-ISO) - P. tricornotum I/P y I. galbana (clone T-ISO) - $P$. tricornotum- T. suecica $\mathrm{I} / \mathrm{P} / \mathrm{T}]$

\section{EFFECT OF DIET ON POSTLARVAL CULTURE}

By day 31 (12 days of PL culture), there were already significant differences in valve length among the PL fed with different diets (Fig. 2); they remained significantly different until the end of the experiment (Table 2). The greatest mean lengths were shown by those fed with the $I / P / T(534 \pm 80 \mu \mathrm{m}), I / P(523 \pm 73 \mu \mathrm{m})$ and $I(521 \pm 83 \mu \mathrm{m})$ diets. One of the replicas of diet $T$ was contaminated by protozoa in the first week of culture and was eliminated. The PL fed with the $P$ and $T$ diets grew less; their mean lengths were $482 \pm 53 \mu \mathrm{m}$ and $472 \pm 41 \mu \mathrm{m}$, respectively.
The mean daily growth rate for the first group of diets (I/ $P / T, I / P, I)$ was $39 \mu \mathrm{m}$, and for the second group $(P, T), 31$ $\mu \mathrm{m}$.

By day 37 the difference between the 2 groups of diets was notable, and continued to increase in the following days. The daily growth with diets $P$ and $T$ was only $6 \mu \mathrm{m}$ from days 31 to 37 . By contrast, the diets which included I. galbana (I/P/T, I/P, I) produced much more growth in valve length; their daily growth rates were greater than $100 \mu \mathrm{m}$ at day 50 (Fig. 2). The mean lengths at day 50 were $2225 \pm 430 \mu \mathrm{m}$ for $I, 2042 \pm 374$ for $I / P$ and $1974 \pm 439 \mu \mathrm{m}$ for $I / P / T$. The mean valve lengths of the PL fed with $P$ and $T$ were $806 \pm 241 \mu \mathrm{m}$ and $720 \pm 148 \mu \mathrm{m}$, respectively.

The survival of the PL did not vary among diets at any point of the experiment. Although at day 50 the survival was $30 \%$ with diet $I / P / T$ and $19 \%$ with $P$, the difference was not significant (Table 3).

\section{Discussion}

Larval stocking density is an important factor in determining the efficiency of hatchery production (Hurley \& Walker 1996, Doroudi \& Southgate 2000). This may be extended to PL culture. In this study, the greatest growth rate of PL was obtained at a density of $5 \mathrm{PL} \mathrm{cm}{ }^{-2}$. There are a number of similar studies which have estimated optimum culture density for the clams Spisula solidissima similis, Meretrix meretrix and Paphia malabarica, but the majority have dealt with the larval stage (Hurley \& Walker 1996, Liu et al. 2006, Gireesh \& Gopinathan 2008 a,b). Yan et al. (2006) found that larval growth decreased significantly with increasing stocking density for the manila clam, Ruditapes philippinarum; a density of 5-10 larvae $\mathrm{ml}^{-1}$, appeared to be optimal for normal growth of manila clam larvae, while for Mulinia edulis the optimum density was 10 larvae $\mathrm{ml}^{-1}$.

The stocking density in filtering mollusks has been generally calculated based on volumetric densities rather than area in the postlarval stage (Taylor et al. 1998, Doroudi \& Southgate 2000). The studies of density have focused on seeds, longer than $3 \mathrm{~mm}$ (Hadley \& Manzi 1984, Doménech 1994, Liu et al. 2002, Royo et al. 2005 a, b).

Gireesh \& Gopinathan (2008a) suggested that in larvae of the clam Paphia malabarica an increase in density generates a greater quantity of metabolic waste which is detrimental to larval growth. Also, greater larval density produces an increase in competition for food and space 
Table 2. Paired comparisons of mean length in diet treatments [Isochrysis galbana (clone T-ISO) I, Phaeodactylum tricornotum $\mathrm{P}$, Tetraselmis suecica $\mathrm{T}$, I. galbana (clone T-ISO) - P. tricornotum I/P and $I$. galbana (clone T-ISO) - P. tricornotum- . suecica $\mathrm{I} / \mathrm{P} / \mathrm{T}]$ at different times using the Kruskal-Wallis test [different letters were significantly different $(\boldsymbol{P}<\mathbf{0 . 0 5})$ ] / Comparaciones pareadas de la longitud media de los diferentes tratamientos de dieta [Isochrysis galbana (clon T-ISO) I, Phaeodactylum tricornotum $\mathrm{P}$, Tetraselmis suecica T, I. galbana (clone T-ISO) - P. tricornotum I/P e I. galbana (clone T-ISO) - P. tricornotum- $T$. suecica $\mathrm{I} / \mathrm{P} / \mathrm{T}$ ] en el tiempo usando la prueba de Kruskal-Wallis [distintas letras son significativamente diferentes $(P<0,05)]$

\begin{tabular}{ccccc}
\hline Diet/Time & Day 31 & Day 37 & Day 43 & Day 50 \\
\hline $\mathrm{I}$ & $\mathrm{a}$ & $\mathrm{a}$ & $\mathrm{a}$ & $\mathrm{a}$ \\
$\mathrm{P}$ & $\mathrm{b}$ & $\mathrm{b}$ & $\mathrm{c}$ & $\mathrm{c}$ \\
$\mathrm{T}$ & $\mathrm{b}$ & $\mathrm{c}$ & $\mathrm{c}$ & $\mathrm{c}$ \\
$\mathrm{I} / \mathrm{P}$ & $\mathrm{a}$ & $\mathrm{a}$ & $\mathrm{b}$ & $\mathrm{b}$ \\
$\mathrm{I} / \mathrm{P} / \mathrm{T}$ & $\mathrm{a}$ & $\mathrm{a}$ & $\mathrm{a} \mathrm{b}$ & $\mathrm{b}$ \\
\hline
\end{tabular}

Table 3. Survival (Mean \pm SD) of Mulinia edulis postlarvae (PL) fed with 5 different diets [/sochrysis galbana (clone T-ISO) I, Phaeodactylum tricornotum P, Tetraselmis suecica T, I. galbana (clone T-ISO) - P. tricornotum I/P and I. galbana (clone T-ISO) - P. tricornotum- T. suecica I/P/T] / Supervivencia (Media \pm DE) de postlarvas ( $\mathrm{PL}$ ) de Mulinia edulis alimentadas con 5 diferentes dietas [Isochrysis galbana (clone T-ISO) I, Phaeodactylum tricornotum P, Tetraselmis suecica T, I. galbana (clone T-ISO) - P. tricornotum I/P e I. galbana (clone T-ISO) - P. tricornotum- T. suecica I/P/T]

\begin{tabular}{cccccc}
\hline $\begin{array}{c}\text { Stocking Density/ } \\
\text { PL Age }\end{array}$ & \multicolumn{5}{c}{$\begin{array}{c}\text { Survival } \\
\text { (Mean } \pm \text { SD) }\end{array}$} \\
& $\mathrm{I}$ & $\mathrm{P}$ & $\mathrm{T}$ & $\mathrm{I} / \mathrm{P}$ & $\mathrm{I} / \mathrm{P} / \mathrm{T}$ \\
\hline Day 19 & 100 & 100 & 100 & 100 & 100 \\
Day 37 & $25.2 \pm 4.7$ & $18.9 \pm 6.6$ & $22.3 \pm 13.4$ & $28.5 \pm 5.3$ & $29.6 \pm 6.1$ \\
Day 43 & $24.6 \pm 5.5$ & $20.9 \pm 4.8$ & $26.4 \pm 11.4$ & $29.4 \pm 5.0$ & $30.2 \pm 6.6$ \\
Day 50 & $24.7 \pm 5.0$ & $19.2 \pm 4.7$ & $24.8 \pm 10.8$ & $28.5 \pm 4.4$ & $30.0 \pm 7.7$ \\
\hline
\end{tabular}

when they are fed with fixed rations of microalgae (Hurley \& Walker 1996, Liu et al 2006, Marshall et al. 2010). Interspecific differences make the comparison of different species of clams difficult; for example Cyclina sinensis (Liu et al. 2002) has a larval period and size at metamorphosis very inferior to those of $M$. edulis, which allows the former species to be cultured at a postlarval density of 723 seeds $\mathrm{cm}^{-2}$.

At the greatest density used in our study, $20 \mathrm{PL} \mathrm{cm}^{-2}$, we obtained the smallest sizes and least survival; this density is not recommended in a closed system such as we used. An efficient system of re-circulation or open flow might allow a greater density or allow maximization of hatchery efficiency; this is still to be investigated.

The criteria generally used to evaluate diets are acceptability, digestibility, growth and biochemical composition (Albentosa et al. 1996b, Marshall et al. 2010). We used only the growth criterion; however the other criteria help to understand the results obtained. Our results indicate that the optimum diet, which produced the greatest shell length for seeds of $M$. edulis, is the monospecific diet of Isochrysis galbana (clone T-ISO), followed by the mixed diets of I. galbana/P tricornutum and I. galbana/P tricornutum/T. suecica. The seeds which had the least growth were those fed on monospecific diets of $P$. tricornutum and T. suecica.

These results are in agreement with those of Yan et al. (2006), who reported that larvae of the Manila clam (Ruditapes philippinarum) showed the greatest growth rate with a monospecific diet of Isochrysis spp. However, Tetraselmis suecica produced a low growth rate for larvae of this species (Laing et al. 1990, Marshall et al. 2010). 
Nevertheless, these results are in contrast to other diet studies such as that of Albentosa et al. (1996a). These authors determined that for seeds of the fine clam Ruditapes decussatus $(700 \mu \mathrm{m})$ the greatest growth rate was obtained with a diet of the microalga Tetraselmis suecica, followed by Isochrysis galbana (clone T-ISO), with the poorest result for Phaeodactylum tricornutum. Albentosa et al. (1993) compared diets I. galbana (clone T-ISO), T. suecica and a mixture of these 2 for the clam Venerupis pullastra, they found that the $50-50 \%$ mixture of the 2 algae produced the greatest growth, followed by I. galbana (clone T-ISO) alone.

Also, a study performed in juveniles $(4 \mathrm{~mm})$ of the oyster Crassostrea corteziensis, Rivero-Rodríguez et al. (2007) evaluated the effect of diet on growth; they reported smaller sizes with I. galbana (clone T-ISO), $T$. suecica and $P$ tricornutum compared to diets of Chaetoceros calcitrans y Chaetoceros muelleri. These results demonstrate the different nutritional requirements of bivalve species; thus it is necessary to determine the requirements of each species and not extrapolate to other species (Albentosa et al. 1996b, Rivero-Rodríguez et al. 2007).

The small size obtained in seeds of M. edulis fed with T. suecica may be due to the difficulty of digestion of the complex of polysaccharides and proteins of the theca (Epifanio 1979), and thus limit its nutritional value. Another possible explanation is the absence of docosahexaenoic acid (DHA; 22:6n-3) in T. suecica (Rivero-Rodríguez et al. 2007, Albentosa et al. 1994). In bivalve seeds, 20:5n-3 and 22:6n-3 polyunsaturated fatty acids are essential to support growth (Langdon \& Waldock 1981).

According to Epifanio (1983), the most consistent factor to explain the low nutritional quality of a microalga is its indigestibility. P. tricornutum is a microalga which is difficult to digest; Lora-Vilchis \& Maeda-Martínez (1997) found ingestion but not digestion of this species in larvae of the oyster Argopecten ventricosus-circularis. This fact could explain the differences in the growth of M. edulis with this diet.

I. galbana (clone T-ISO) diet had the best performance for PL of M. edulis; its high nutritional value may be related to higher ingestion, digestion, and absorption. This microalga is also an optimum diet for the clam Paphia malabarica (Girresh \& Gopinathan 2008b) and for Meretrix meretrix (Tang et al. 2006), both studies obtained the best growth (increase in shell length) and survival with I. galbana. Tang et al. (2006) also reported that the larvae of Meretrix meretrix showed a preference for $I$. galbana when it was offered together with another species of microalga; this feeding behavior may also be related to essential nutrients and the morphology and size of the algae.

A diet of I. galbana (clone T-ISO), alone or mixed with Chlorella spp., produced the greatest growth and highest percentage of metamorphosized larvae in the clam Ruditapes philippinarum (Yan et al. 2006). The same result was found for Paphia malabarica fed with a mixture of the microalgae I. galbana and Nannochloropsis salina (Gireesh \& Gopinathan 2008b). Bivalve larvae are generally fed with a mixture of microalgae species to provide a better nutrient balance (Southgate 2003).

Helm \& Laing (1987) obtained good growth with $I$. galbana (clone T-ISO) for larvae of the clams Tapes semidecussata and Mercenaria mercenaria, but not for the oyster Crassostrea gigas or the mangrove oyster, Crassostrea rhizophore. I. galbana (clone T-ISO) can be beneficial as a constituent species of a mixed algal diet, as shown by significantly improved growth of the larvae of three of the four bivalves tested.

A number of studies have demonstrated that both the quantity and quality of food affect the growth and survival in the larval stages (Hurley et al. 1997), fixation and growth of clam seeds (Castagna \& Kraeuter 1981). These results also illustrate the importance of feeding the correct ratio of different species in any food mixture to give the most efficient utilization of the diet and to obtain the best growth.

We did not detect significant differences in survival with different diets after 50 days of culture. However, our results showed that mixed diets gave better mean survival than monospecific diets. This was not true for Meretrix meretrix; those fed with I. galbana, had greater survival than those with mixed diets (Liu et al. 2006).

The presence of Isochrysis galbana in the best diet in our study may be explained by its high concentration of proteins and lipids (Albentosa et al. 1994), while Tetraselmis has a greater quantity of carbohydrates, which along with Tetraselmis may have provided other compounds which improved survival.

Mulinia edulis is a species resistant to management, since its survival was not affected by the diet, or stocking density. The high percentages of survival (up to 25\%) obtained in the experiment on food concentration confirmed this. 
The differences obtained in the growth of seeds with different diets and culture density suggest that to optimize PL culture, metamorphosis and later culture of Mulinia edulis seeds, they should be fed a monospecific diet of the microalga Isochrysis galbana (clone T-ISO), and cultured at a density of $5 \mathrm{PL} \mathrm{cm}^{-2}$. As we hypothesized, a low stocking density resulted in a better growth rate for the PL, but the Isochrysis galbana unialgal diet had a better performance than the mixed diets that we had expected.

Although these factors were studied independently, the results for each of them represent an important advance in the development of a protocol of optimum culture for seeds of $M$. edulis with good growth and a high survival percentage; and thus represent a key to the future commercial culture of the species.

\section{ACKNOWLEDGMENTS}

The authors wish to thank Humberto Monsalve and Rafael Sepúlveda, of Pesquera San José, for providing facilities for the experiments, the technical team of the hatchery for their help, René Durán for important comments on the manuscript and Lafayette Eaton for reviewing and improving the English. We also thank FONDEF for the financial support (Project D98I1081, AQ08I-1027) and CORFO FONTEC 202-3032.

\section{LITERATURE CITED}

Abarca A, D Oliva, R Gutiérrez, A Celis \& LR Durán. 2012. Grown-out of seeds of the taquilla clam Mulinia edulis (King \& Broderip, 1832) in the subtidal zone in northern Chile and in the intertidal zone in southern Chile. Latin American Journal of Aquatic Research 40: 694-704.

Albentosa M, A Pérez-Camacho, U Labarta, R Beiras \& MJ Fernández-Reiriz. 1993. Nutritional value of algal diets to clam spat Venerupis pullastra. Marine Ecology Progress Series 97: 261-269.

Albentosa M, U Labarta, A Pérez-Camacho, MJ FernándezReiriz \& R Beiras. 1994. Fatty acid composition of Venerupis pullastra spat fed on different microalgae diets. Comparative Biochemistry and Physiology 108A: 639-648.

Albentosa M, A Pérez-Camacho \& R Beiras. 1996a. The effect of food concentration on the scope for growth and growth performance of Ruditapes decussatus (L) seed reared in an open-flow system. Aquaculture Nutrition 2: 213-220.

Albentosa M, A Pérez-Camacho, U Labarta \& MJ Fernandez-Reiriz. 1996b. Evaluation of live microalgal diets for seed culture of Ruditapes decussatus using physiological and biochemical parameters. Aquaculture 148: 11-23.
Castagna M \& JN Kraeuter. 1981. Manual for growing the hard clam Mercenaria. Special Report in Applied Marine Science and Ocean Engineering 249: 1-110. Virginia Institute of Marine Sciences, Gloucester Point.

Doménech JL. 1994. Cultivo sin sustrato de la almeja fina, Ruditapes decussatus (Linnaeus, 1758), en la ría de Villaviciosa (Asturias). Boletín, Instituto Español de Oceanografía 10: 23-32.

Doroudi M \& PC Southgate. 2000. The influence of algal ration and larval density on growth and survival of blacklip pearl oyster (Pinctada margaritifera L.) larvae. Aquaculture Research 31: 621-626.

Epifanio CE. 1979. Growth in bivalve mollusc: nutritional effects of two more species of algae in diets fed to the American oyster Crassostrea virginica (Gmelin) and the hard clam Mercenaria mercenaria (L.). Aquaculture 18: 1-12.

Epifanio CE. 1983. Phytoplankton and yeast as foods for juvenile bivalves: a review of research at the University of Delaware. In: Pruder GD \& C Langdon (eds). Biochemical and physiological approaches to shellfish nutrition, pp. 292-304. Proceedings $2^{\text {nd }}$ International Conference on Aquaculture Nutrition, Baton Rouge.

Gireesh R \& CP Gopinathan. 2008a. Effects of diet, stocking density and environmental factors on growth, survival and metamorphosis of clam, Paphia malabarica (Chemnitz) larvae. Aquaculture Research 39: 928-933.

Gireesh R \& CP Gopinathan. 2008b. Effects of microalgal diets on larval growth and survival of Paphia malabarica Chemnitz. Aquaculture Research 39: 552-556.

Hadley NH \& JJ Manzi. 1984. Growth of seed clams, Mercenaria mercenaria, at various densities in a commercial scale nursery system. Aquaculture 36: 369-378.

Helm MM \& I Laing. 1987. Preliminary observation on the nutritional value of 'Tahitian Isochrysis' to bivalve larvae. Aquaculture 62: 281-288.

Hurley D \& R Walker. 1996. The effects of larval stocking density on growth, survival, and development of laboratoryreared Spisula solidissima similis (Say, 1822). Journal of Shellfish Research 15: 715-718.

Hurley D, R Walker \& F O’Beirn. 1997. Growth and survival of Spisula solidissima similis larvae fed different rations of Tahitian Strain Isochrysis species. Journal of Shellfish Research 16: 151-157.

Laing I, AR Child \& J Achim. 1990. Nutritional values of dried algae for diets for larvae of Manila clam (Tapes philippinarum). Journal of the Marine Biological Association of the United Kingdom 70: 1-12

Langdon CJ \& MJ Waldock. 1981. The effect of algal and artificial diets on the growth and fatty acid composition of Crassostrea gigas. Journal of the Marine Biological Association of the United Kingdom 61: 431-448. 
Liu W, Y Ma, S Hu, G Miao \& J Li. 2002. Rearing Venus clam seeds, Cyclina sinensis (Gmelin), on a commercial scale. Aquaculture 211: 109-114.

Liu B, B Dong, B Tang, T Zhang \& J Xiang. 2006. Effect of stocking density on growth, settlement and survival of clam larvae, Meretrix meretrix. Aquaculture 258: 344-349.

Lora-Vilchis MC \& AN Maeda-Martínez. 1997. Ingestion digestion index of catarina scallop Argopecten ventricosus (circularis, Sowerby II, 1842), veliger larvae with ten microalgae species. Aquaculture Research 28: 905-910.

Martínez-Fernández E, H Acosta-Salmón \& P Southgate. 2006. The nutritional value of seven species of tropical microalgae for black-lip pearl oyster (Pinctada margaritifera, L) larvae. Aquaculture 257: 491-503.

Oliva D, A Cifuentes, A Abarca, R Farlora, P Vera, LR Durán, J Urra, A Urra, D Brown, A Celis \& R Gutiérrez. 2005. Manual cultivo comercial de la almeja fina chilena, Mulinia edulis, 60 pp. Universidad de Valparaíso, Valparaíso.

Rivero-Rodríguez S, A Beaumont \& MC Lora-Vilchis. 2007. The effect of microalga diets on growth, biochemical composition, and fatty acid profile of Crassostrea corteziensis (Hertlein) juveniles. Aquaculture 263: 199-210.

Royo A, P Ruiz-Azcona \& R Navajas. 2005a. Evolución en la fase de engorde de las anomalías aparecidas en las valvas de la almeja japonesa Ruditapes philippinarum (Adams \& Reeve, 1850) durante su preengorde. In: Mosquera de Arancibia C, I Arnal-Atarés, M Jover-Cerdá \& F de la Gándara (eds). X Congreso Nacional de Acuicultura: La acuicultura, fuente de pescado de calidad para el futuro. Boletín, Instituto Español de Oceanografía 21: 431-440.

Royo A, P Ruiz \& R Navajas. 2005b. Preengorde intensivo de almeja japonesa Ruditapes phiippinarum (Adams \& Reeve, 1850) en sustrato, en la zona intermareal. En: Mosquera de
Arancibia C, I Arnal-Atarés, M Jover-Cerdá \& F de la Gándara (eds). X Congreso Nacional de Acuicultura: La acuicultura, fuente de pescado de calidad para el futuro. Boletín, Instituto Español de Oceanografía 21: 447-454.

SERNAPESCA. 2010. Anuario estadístico de pesca. Servicio Nacional de Pesca, Valparaíso. <http.//www.sernapesca.cl>

Sokal RR \& F J Rohlf. 1981. Biometry, 859 pp. W.H. Freeman, New York.

Southgate PC. 2003. Feeds and fed production. In: Lucas JS \& PC Southgate (eds). Aquaculture: Farming aquatic animals and plants, pp. 172-198. Blackwell Publishing, Oxford.

Southgate P, A Beer, P Duncan \& R Tamburri. 1998. Assessment of the nutritional value of three species of tropical microalgae, dried Tetraselmis and a yeast-based diet for larvae of the blacklip pearl oyster, Pinctada margaritifera (L). Aquaculture 162: 247-257.

Tang B, B Liu, G Wang, T Zhang \& J Xiang. 2006. Effects of various algal diets and starvation on larval growth and survival of Meretrix meretrix. Aquaculture 254: 526-533.

Taylor J, P Southgate, R Rose \& A Keegan. 1998. Effects of larval set density on subsequent growth and survival of the silver-lip pearl oyster Pinctada maxima (Jameson). Journal of Shellfish Research 17: 281-283.

Wang X, B Liu, G Wang, B Tang \& J Xiang. 2008. Molecular cloning and functional analysis of cathepsin B in nutrient metabolism during larval development in Meretrix meretrix. Aquaculture 282: 41-46.

Yan X, G Zhang \& F Yang. 2006. Effects of diet, stoking density, and environmental factors on growth, survival, and metamorphosis of Manila clam Ruditapes phiippinarum larvae. Aquaculture 253: 350-358.

Zar JH. 1999. Biostatistical analysis, 662 pp. Prentice Hall, Upper Saddle River. 